\title{
INFLUÊNCIAS ORIENTAIS NAS LITERATURAS HISPÂNICAS MEDIEVAIS: JARCHAS, CALILA E DIMNA, LIBRO DE APOLONIO, EL CONDE LUCANOR
}

\author{
ORIENTAL INFLUENCES ON MEDIEVAL HISPANIC \\ LITERATURES: JARCHAS, CALILA E DIMNA, LIBRO DE APOLONIO, \\ EL CONDE LUCANOR
}

José Alberto MIRANDA POZA*

\begin{abstract}
Resumo: Em nosso trabalho, revisitaremos alguns dos conceitos tradicionalmente desenvolvidos pela História e a Crítica literária referentes à própria concepção de Idade Média na Península Ibérica, focando nas relações políticas, sociais e culturais que se produziram entre as culturas que conviveram nesse período, em especial, das conturbadas relações entre o Islamismo e o Cristianismo. Embasados nos trabalhos clássicos de Américo Castro a propósito da História da Espanha (2004), junto com as propostas de Maravall (1954), demonstraremos a teoria de uma convivência não apenas cultural, mas, sobretudo, social e política entre as culturas que povoaram a Península, o qual abriu a possibilidade de uma influência palpável nas manifestações literárias da época, com a subsequente intertextualidade. Por sua vez, a cultura árabe recebera uma influência indubitável do Oriente, o que produziu que a literatura romanceada tivesse mais uma fonte de inspiração. Coube ao criador medieval peninsular a tarefa de adaptar esses referentes à realidade espaço-temporal da sua contemporaneidade, em especial no âmbito da religiosidade.
\end{abstract}

Palavras-Chave: Idade Média Peninsular. Orientalismo. Residualidade. Literatura Hispânica Medieval.

\begin{abstract}
This paper presents a review on some of the concepts traditionally developed by History and Literary Criticism regarding the very conception of the Middle Ages in the Iberian Peninsula, focusing on the political, social and cultural relations that took place between the cultures during this period, in particular, the troubled relations between Islam and Christianity. Based on the classic works of Américo Castro, regarding the history of Spain (2004) and with Maravall's (1954) proposals, it seeks to demonstrate the theory of a not only cultural, but, above all, social and political coexistence between cultures that populated the Peninsula, which opened up the possibility of a tangible influence on literary manifestations of the time, with the subsequent intertextuality. Arab culture also received an undoubted influence from the East, which made that romance literature have another source of inspiration. The medieval peninsular creator was responsible for the task of adapting these references to the spatiotemporal reality of their contemporaneity, especially in the scope of religiousness.
\end{abstract}

Keywords: Peninsular Middle Ages. Orientalism. Residuality. Medieval Hispanic Literature.

\footnotetext{
* Doutor em Filologia (Programa: Linguística Histórica, História da Língua e Crítica do Texto) pela Universidad Complutense de Madrid, Espanha; Professor Associado de Língua Espanhola e Literaturas Hispânicas do Departamento de Letras da Universidade Federal de Pernambuco (UFPE), e de Linguística e Teoria da Literatura no Programa de Pós-Graduação em Letras (PPGL/UFPE). E-mail: ampoza@globo.com. ORCID: https://orcid.org/0000-0003-3280-4786.
} 


\section{A propósito da Idade Média}

Aproximar-se hoje da leitura de textos medievais supõe intentar analisar as circunstâncias históricas em que foram escritos os códigos culturais da época em que os autores se moviam e mostrar o tipo de leitor-ouvinte para quem foram elaborados (CORBELLA, 1992). Nesse sentido, a primeira referência obrigatória é o papel do cristianismo no Ocidente (MIRANDA POZA, 2013) e sua relevância na transmissão cultural, mais em concreto, dos mosteiros, pois nos scriptoria das bibliotecas se elaboravam e conservavam textos de obras literárias (e de outras temáticas) da Antiguidade (MIRANDA POZA, 2011). Ainda, cabe frisar, a propósito da denominação "livro", que aparece em não poucos títulos de obras da época, que não significava apenas "volume formado por folhas de papel ou vitela", mas também "marco ordenador de certo conteúdo textual" (MICHAEL, 1986, p. 510).

Por outro lado, cabe mencionar a questão da originalidade: a intertextualidade é inevitável. Para Todorov (1972, p. 28, tradução nossa): "tudo o que é novo em literatura não é senão material antigo forjado de novo". ${ }^{1}$ Quase nos mesmos termos, Claudio Guillén (1985, p. 220, tradução nossa) afirma: "não há literatura sem aceitação, realização, transformação ou transgressão de certos modelos arquetípicos". ${ }^{2} \mathrm{Na}$ literatura medieval se parte de outro conceito de literalidade diferente do que hoje temos:

\footnotetext{
Não se pode esperar que a Idade Média ofereça definições novas ou originais: os medievais [...] ficam satisfeitos com o que eles encontram nos textos antigos, pois [...] esses textos não transmitem apenas o pensamento dos Antigos, mas representam a evidência do senso comum, que é também o bom senso (DE BRUYNE, 1988, p. 15, tradução nossa). ${ }^{3}$
}

A originalidade dos textos medievais radica em apresentar-nos uma tensão entre o local, no caso da Península Ibérica, a adaptação à cultura castelhana e o universal, a cultura e a lenda de tradição clássica que inclui inequívocos traços orientais e pagãos. O medievo realizou uma adaptação e imitação de fórmulas, tipos e motivos que se repetiram por toda

\footnotetext{
${ }^{1}$ No original: "Todo lo nuevo en literatura no es sino material antiguo forjado de nuevo".

${ }^{2}$ No original: "No hay literatura sin aceptación, realización, transformación o transgresión de ciertos modelos arquetípicos".

${ }^{3}$ No original: "No se puede esperar que la Edad Media ofrezca definiciones nuevas u originales: los medievales $[\ldots]$ se quedan satisfechos con lo que encuentran en los textos antiguos, pues [...] esos textos no transmiten solo el pensamiento de los Antiguos, sino que representan la evidencia del sentido común, que es también el buen sentido".
} 
Europa e que representaram a atualização e revisão de registros clássicos e orientais. A propósito da adaptação ao imaginário cristão:

Toda conscientização na Idade Média é feita por e através da religião - no plano da espiritualidade. Quase poderia ser definida uma mentalidade medieval pela impossibilidade de expressar-se à margem de referências religiosas (LE GOFF, 1983 , p. 57, tradução nossa). ${ }^{4}$

\section{A Idade Média na Península Ibérica. Convivência de culturas: aspectos políticos, culturais e sociais. $O$ problema de Espanha: residualidade e ressonâncias}

Na nossa atividade habitual no magistério de língua, literatura e culturas hispânicas surge com força o questionamento por parte dos estudantes a propósito da realidade política e cultural que se vivencia atualmente na Espanha. Fala-se principalmente do fato de existirem num território tão pequeno em relação com o Brasil até quatro línguas oficiais diferentes galego, catalão, basco, além do espanhol - e, sobretudo, as fortes manifestações políticosociais que reclamam a independência / emancipação da Espanha, principalmente na Catalunha e no País Basco. A resposta - independente do mérito da reivindicação - sempre se encontra na História.

Nesse sentido, é muito estendido o conceito de Espanha como "unidade imperialista", capaz de colonizar quase um continente de um modo uniforme. Essa visão, relativamente unânime na Academia nos Estudos Pós-coloniais, merece um questionamento do ponto de vista cultural, histórico e político. As plurais manifestações literárias na Península, a todo momento, reflexo da diversidade cultural e idiomática - com evidentes consequências sóciopolíticas - questionam a teoria dessa suposta unidade pétrea. Por sua vez, as evidências de tais manifestações atrelam esta questão ao denominado problema da Espanha (TUSÓN; LÁZARO, 1980), assunto que já tivemos ocasião de abordar em outros trabalhos (MIRANDA POZA, 2015, 2019; PEREIRA; MIRANDA POZA, 2015) e que pode ser resumido de forma plástica na afirmação de VICENS-VIVES (2012, tradução nossa): “entre as grandes nações que surgiram no Renascimento, apenas Espanha se perguntou se ela realmente existia"5. Identidades e multiculturalismo são hoje o foco de uma perspectiva plural de uma Espanha

\footnotetext{
${ }^{4}$ No original: “Toda toma de conciencia en la Edad Media se produce por y a través de la religión -en el plano de la espiritualidad-. Casi podría definirse la mentalidad medieval por la imposibilidad de expresarse al margen de referencias religiosas".

${ }^{5}$ No original: "Entre las grandes naciones que surgieron en el Renacimiento, solo España se preguntó si realmente existía".
} 
reconhecida como "Nação de nações". Em tempos de efervescentes pesquisas na área dos Estudos Culturais, é pertinente a possibilidade de discutir o tema da identidade e do nacionalismo através das manifestações literárias em um cenário único para a questão: a multiplicidade de identidades nacionais existentes no "pequeno" território espanhol. Nesse sentido, a nação "é uma comunidade imaginada e que não importa quão diferentes seus membros possam ser em termos de classe, gênero ou raça, uma cultura nacional busca unificá-los numa identidade cultural, para representá-los todos como pertencendo à mesma e grande família nacional" (HALL, 2006, p. 59). No entanto, o que mais suscita o interesse no caso da Espanha é seu caráter paradoxal quanto à identidade, pois sabemos que vivemos na era da celebração de identidades móveis, o homem pós-moderno está em constante metamorfose. Mas a questão da identidade no território espanhol revolve séculos de luta ideológica e opressão, tendo na identidade nacional uma possibilidade de libertação de um passado repressor para as subjugadas micronações espanholas: Catalunha, Galícia e País Basco. Dessa forma, esse é um caso em que “a formação de 'enclaves' étnicos minoritários no interior dos Estados-Nação do ocidente levou a 'pluralização' de culturas nacionais e de identidades nacionais" (HALL, 2006, p. 83). Há, portanto, uma reafirmação constante e atual da identidade micronacional como forma de liberdade diante de um histórico poder unificador fracassado: Castela (ligada intrinsecamente à ideia de Espanha).

E não apenas na História, mas, sobretudo, nas perspectivas em como essa História foi / é relatada, e ainda a qualificação dessa(s) narrativa(s) que normalmente giram ao redor dos adjetivos "verdadeira", "única"6. É por isso que aqui os conceitos de residualidade e ressonância, referidos por Pontes (2015), fazem-se presentes e são pertinentes.

$\mathrm{Na}$ Teoria da Residualidade, Pontes defende as relações híbridas que as culturas e, por conseguinte, as literaturas, mantêm entre si, numa incessante retomada de elementos de outros tempos e espaços que permanecem vivos no processo cultural: os resíduos.

Com efeito, em especial, no longo período da ditadura franquista (1939-1975), a doutrina espalhada não apenas nos meios oficiais, mas sobretudo através do ensino na escola, era uma visão, simplista e quase infantil, da suposta existência secular de uma "España una", termo cunhado e questionado criticamente havia décadas pelo prestigioso filósofo espanhol

\footnotetext{
${ }^{6}$ A propósito da "veracidade" dos fatos relatados, resulta esclarecedora a citação de uma das "enciclopédias", isto é, "livros didáticos", mais recomendadas na época da ditadura como material escolar, inclusive com nihil obstat da autoridade eclesiástica - censor - na capa: "Noções: História da Espanha. História da Espanha é a narração verídica dos fatos realizados pelos espanhóis dos tempos mais remotos até nossos dias" (ÁLVAREZ, 2000, p. 402).
} 
Ortega y Gasset ${ }^{7}$. Ele conseguiu analisar com lucidez a situação social da Espanha, conjugando a perspectiva histórica e a contemporaneidade. O processo assimilativo consistia numa tarefa de totalização: grupos sociais isolados na origem ficavam integrados como partes de um todo. A desintegração é o evento contrário: as partes do todo começam a viver como todos isolados. A este fenômeno da vida histórica Ortega chama de "particularismo" e, para ele, esse era, precisamente, o caráter mais aprofundado e mais grave da atualidade espanhola; na sua época e, ainda hoje, acrescentamos com a consequente repercussão na literatura espanhola e hispânica.

A concepção de uma "España una", muito além dos limites marcados pela linha do tempo, levou a interpretações assimiladoras que consideravam "Espanha" a época imperial romana. E, nesse sentido, personagens históricos das letras, da ciência, das artes, seriam "espanhóis" - avant la lettre. Frente a essa visão simplista, já se alçaram vozes autorizadas: que Sêneca "se sentisse espanhol" ou que seu pensamento fosse o de "um romano helenizado" tem menos interesse que o fato certo de que a história do seu pensamento tenha influenciado

\footnotetext{
${ }^{7}$ Para entender essa situação, é necessário ir à história da Espanha, à formação de seus povos, de suas línguas e de suas literaturas. A Península Ibérica no tempo do Império Romano compreendia o território dominado conhecido como Hispania. Nessa época, conviviam diversos povos conquistados por Roma, mas que conseguiam manter seus costumes particulares e sua tradição cultural. A situação se modificou em finais da Idade Média com a queda do Império Romano e a conseguinte desaparição do Latim, quando já existiam as primeiras incidências das línguas neolatinas, unidas diretamente ao processo de formação de estados nacionais. Os grupos culturais que habitavam o histórico território da Hispania romana "uniram-se" por diversos meios (guerras, matrimônios, submissão com conservação de foro próprio) para a formação dos estados. É assim que se chegou, através de um longo período de conquista, reconquista e reunificação (povos germânicos, colonização árabe, Reconquista) a uma Hispania com dois estados: Portugal e Espanha. O estado que passou a responder pelo nome romanceado "Espanha" era composto por uma variedade de povos e línguas que tiveram que ser oprimidas em favor de uma ideologia de unificação, o que fez com que Catalunha, Galícia e País Basco ficassem subjugados à força política da histórica Castela. Nesse momento, a época dos Reis Católicos, a ideia de unificação em estado nacional exigia que todos da nova nação partilhassem uma língua comum, e foi assim que definitivamente o castelhano ficou estabelecido como língua oficial em detrimento das outras línguas com menos falantes e menos poder. Foi assim que o castelhano se converteu em espanhol e passou a ser a língua oficial de cultura tanto no território peninsular espanhol quanto na América hispânica, como consequência do processo de expansão da coroa castelhana pelo Atlântico. Essa unificação, contudo, não obteve sucesso em seu objetivo: A "Espanha Uma" nasce na mente de Castela, não como una intuição de algo real, pois Espanha não era em realidade uma, mas como um esquema ideal de algo realizável (ORTEGA Y GASSET, 1922). De fato, a tentativa de unificar os povos de Espanha rendeu séculos de negação das manifestações linguísticas e literárias dos povos periféricos da grande nação espanhola que viram, a partir dos séculos XV e XIV - período histórico que coincidiu com a época de máximo esplendor da literatura escrita em língua castelhana, já convertida em "literatura espanhola": O Século de Ouro -, a época de decadência de suas literaturas tanto nas mais desenvolvidas (galega e catalã), quanto na literatura basca, que começava sua modalidade escrita. A retomada efetiva da tradição literária dessas línguas só veio a acontecer no século XIX, no contexto ideológico do Romantismo, que também iluminou as manifestações da identidade nacional e das primeiras incidências de separatismo. Exposta a situação histórica de Espanha, podemos entender melhor a presença da discussão constante sobre identidade nacional durante fins do século XIX, século XX e "a todo vapor" atualmente. Vemos que a identidade parece ser um grito de guerra usado numa luta defensiva: um indivíduo contra o ataque de um grupo, um grupo menor e mais fraco (por isso, ameaçado) contra uma totalidade maior e dotada de mais recursos (e por isso ameaçadora). Pode-se ver a faca da identidade brandida nas duas direções e cortando dos dois lados nos períodos de "construção nacional": em defesa de línguas, memórias, costumes e hábitos locais, menores, "contra os da capital", que promoviam homogeneidade e exigiam uniformidade (BAUMAN, 2005, p. 83).
} 
as obras de muitos escritores espanhóis de todas as épocas (MARAVALL, 1954). Ou também: "Sêneca não era espanhol, nem os espanhóis eram senequistas" (CASTRO, 1954, p. 642).

Portanto, revisitando criticamente o conceito de Espanha, podemos afirmar que a Idade Média cristã, após os séculos visigóticos e a expansão do Islã pela Península Ibérica, representou a tarefa de os grupos cristãos subsistirem frente a um mundo que era superior em tudo. A presença muçulmana não terminou em 1492: permaneceram os mouriscos, súbditos do rei, que em realidade conservavam sua religião, com a subsequente influência cultural e literária que ultrapassa claramente os nove séculos de invasão. ${ }^{8}$ Tomando como referência inicial a obra Disciplina clericalis, que no século XIII difundiu trinta e três contos de procedência oriental pela Espanha cristã e pela Europa, até El Criticón, de Baltasar Gracián (séc. XVII), cuja base é um relato conservado entre mouriscos aragoneses, a literatura espanhola bebeu de fontes árabes.

Com efeito, e frente a narrativas que afirmaram o contrário, não houve separação geográfica e/ou racial entre cristãos e muçulmanos (CASTRO, 2004). Isso propiciou a convivência de diversas realidades sociais, misturadas. Nesse sentido, cabe falar dos moçárabes, cristãos bilíngues estabelecidos entre os muçulmanos, até as invasões almorávidas (1090) e almoádas (1146). Os mudéjares eram os muçulmanos que viviam como vassalos dos reis cristãos. Por sua vez, os muladis eram cristãos que se islamizavam. Já os tornadizos eram aqueles muçulmanos que se tornavam cristãos. Contudo cabe frisar que o convívio das religiões era aceitável, mas não a apostasia. Caberia falar ainda dos enanciados, que transitavam entre as duas religiões e serviam de espiões pelo seu bilinguismo. Moravam em regiões fronteiriças e, de fato, hoje existe o topônimo Puebla de Naciados na província de Estremadura (Espanha).

Do ponto de vista linguístico, a interação deu lugar a expressões coloquiais do castelhano de origem árabe. Assim, a interjeição ;Olé! < wa-l-lâl "por Deus”. A la paz de Dios (lat. Pax Domini sit vobiscum), é calco semântico da réplica Al-Salām 'alayk. Besar las manos > Besar los pies (Poner(se) a los pies de una dama): No Mio Cid o protagonista tenta beijar os pés do Rei e ele não consente: “Besad las manos, ca los pies non”. Os espanhóis

\footnotetext{
${ }^{8} \mathrm{E}$ voltamos à teoria oficial franquista: "A Reconquista é a luta que durante oito séculos os cristãos mantiveram contra os árabes para expulsá-los da Espanha" (ÁLVAREZ, 2000, p. 429, tradução nossa). Nem tudo foi luta, nem houve expulsão. As manifestações culturais e literárias representam um bom exemplo que contradiz a teoria "oficial". Salientamos que, ainda que tenham se passado mais de quarenta anos, no imaginário hispano ainda aparecem representações dessa visão dos fatos.
} 
cristãos tomaram dos espanhóis muçulmanos esses costumes. Entre os árabes, beijar a mão é sinal de submissão e homenagem. Eles previamente o tomaram de Bizâncio.

Oferecemos a seguir quatro exemplos de manifestações literárias que oferecem indubitáveis ecos dessa influência oriental acima descrita, fruto do verdadeiro convívio de culturas e gentes ao longo da Idade Média peninsular.

\section{As Jarchas (Jarŷas)}

Um escritor árabe do séc. XII relatava que, séculos atrás, na cidade de Cabra, um poeta cego, Mucáddam, inventara um novo gênero da poesia árabe que introduzia versos em língua de cristãos, que mais tarde foi adotado pelos judeus (FRENK ALATORRE, 1978). O gênero caracterizava-se por uma introdução ou cabeça (muwaššaha), que consta de dois, três ou quatro versos, seguida de uma estrofe cujo conteúdo tinha a ver com a introdução, que termina em uns versos, escritos em língua de cristãos (romance): a jarŷa.

A língua das jarŷas é o moçárabe (nem castelhano, nem espanhol, uma língua misturada), isto é, o romance falado na Península (muçulmana) pelos cristãos e pelos árabes bilíngues, língua coloquial, de rua, oral - árabe vulgar e/ou romance cristão - (MIRANDA POZA, 2007, p. 101). Para entender essa situação é necessário ir à história da Espanha, a formação de seus povos, suas línguas e de suas literaturas. A Península Ibérica no tempo do Império Romano compreendia o território dominado conhecido como Hispania. Nessa época, conviviam diversos povos conquistados por Roma, mas que conseguiam manter seus costumes particulares e sua tradição cultural. A situação se modificou em finais da Idade Média com a queda do Império Romano e a conseguinte desaparição do Latim, quando já existiam as primeiras incidências das línguas neolatinas, unidas diretamente ao processo de formação de estados nacionais. Os grupos culturais que habitavam o histórico território da Hispania romana "uniram-se" por diversos meios (guerras, matrimônios, submissão com conservação de foro próprio) para a formação dos estados. É assim que se chegou, através de um longo período de conquista, reconquista e reunificação (povos germânicos, colonização árabe, Reconquista) a uma Hispania com dois estados: Portugal e Espanha. O estado que passou a responder pelo nome romanceado "Espanha" era composto por uma variedade de povos e línguas que tiveram que ser oprimidas a favor de uma ideologia de unificação, o que fez com que Catalunha, Galícia e País Basco ficassem subjugados à força política da histórica Castela. Nesse momento, a época dos Reis Católicos, a ideia de unificação em estado nacional 
exigia que todos da nova nação partilhassem uma língua comum, e foi assim que definitivamente o castelhano ficou estabelecido como língua oficial em detrimento das outras línguas com menos falantes e menos poder. Foi assim que o castelhano se converteu em espanhol e passou a ser a língua oficial de cultura tanto no território peninsular espanhol quanto na América hispânica, como consequência do processo de expansão da coroa castelhana pelo Atlântico. Essa unificação, contudo, não obteve sucesso em seu objetivo: A "Espanha Uma" nasce na mente de Castela, não como uma intuição de algo real, pois Espanha não era em realidade uma, mas como um esquema ideal de algo realizável (ORTEGA Y GASSET, 1922). De fato, a tentativa de unificar os povos da Espanha rendeu séculos de negação das manifestações linguísticas e literárias dos povos periféricos da grande nação espanhola que viram, a partir dos séculos XV e XIV - período histórico que coincidiu com a época de máximo esplendor da literatura escrita em língua castelhana, já convertida em "literatura espanhola": O Século de Ouro -, a época de decadência de suas literaturas tanto nas mais desenvolvidas (galega e catalã), quanto na literatura basca, que começava sua modalidade escrita.

Esse fato leva a certos problemas de interpretação / compreensão / identificação: os poetas hebraicos e árabes não usavam caracteres latinos e nas línguas semíticas não se reproduzem os signos gráficos vocálicos. Eis aqui um exemplo das dificuldades de interpretação, inclusive quando é oferecida a transcrição dos carateres originais semíticos no alfabeto latino (FRENK ALATAORRE, 1978, p. 23):

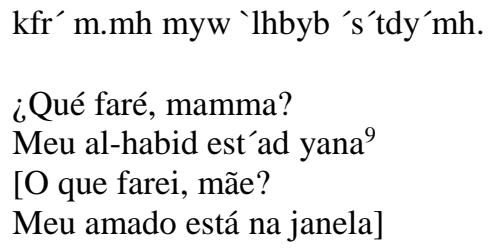

O conteúdo das jarŷas são ingênuos lamentos de ausência amorosa, dolorosas súplicas ao amado ou confidências à mãe ou às irmãs, sempre em boca de uma jovem, embora o autor sempre fosse um homem. As dificuldades linguísticas de interpretação se fazem evidentes, como no exemplo a seguir (ALVAR, 1978, apud MIRANDA POZA, 2007, p. 102-103):

\section{Jarŷa XVII}

\footnotetext{
${ }^{9}$ A forma yana [mozárabe] é relacionada com a forma romanceada janua - literalmente, "porta" -, mais em concreto, do seu diminutivo latino januela, de onde o vocábulo português "janela", que contrasta com o termo semanticamente equivalente em espanhol, "ventana", que, por sua vez, deriva da forma latina ventus.
} 


\begin{abstract}
Al-Lapidi
Quebrou a corça meu coração com suas palavras formosas. Lembou-me de que não podem ser separados com mentiras aqueles que estão unidos entre si. Ela cantou diante de mim, chorando, o canto das gazelas: Adamay filygüelo alyenu ed él a mibi Kyridlu de mi vetari su al-raqībi."

["Amei com paixão um filinho alheio e ele me correspondeu seu espião o quere de mim afastar" $]^{10}$
\end{abstract}

A estrutura global da composição poética, acima mencionada, poderia ser representada através do esquema a seguir:

QUADRO 1 - Esquema da jarŷa

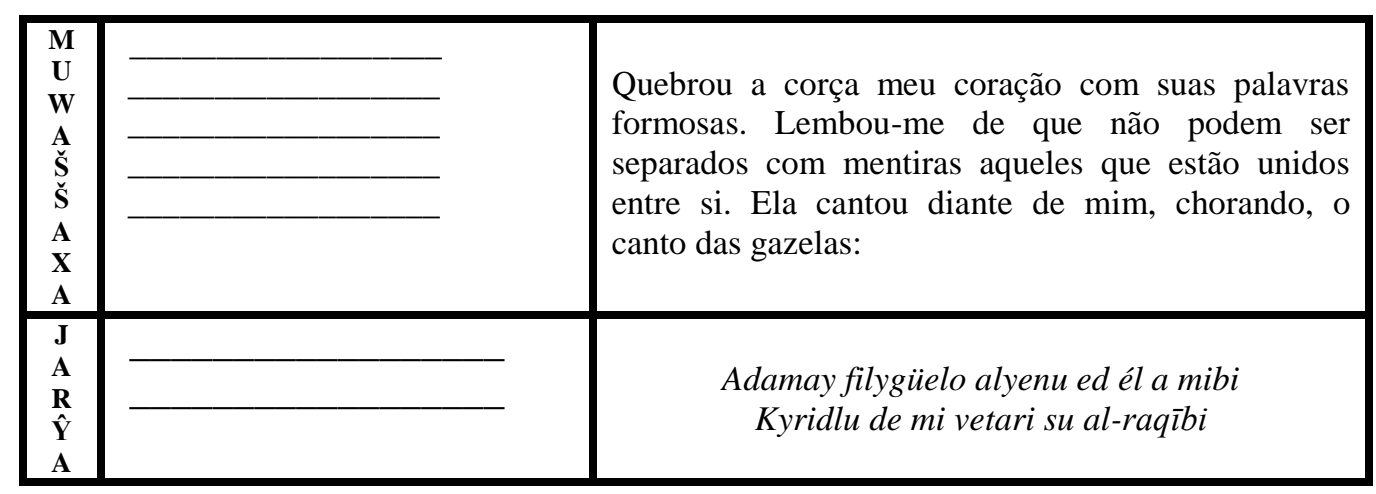

Fonte: adaptado de Miranda Poza (2007, p. 102)

É assim que surge uma das teorias mais estendidas sobre as interrelações entre a lírica andaluza, a galega e a castelhana (ALONSO, 1949; MENÉNDEZ PIDAL, 2014): os

\footnotetext{
${ }^{10}$ Alvar (1978) oferece a tradução da jarcha para o castelhano: "Ha quebrado la corza mi corazón con sus dichos hermosos. Ha recordado que se pueden separar con mentiras a los unidos entre sí. Ha cantado delante de mí, llorando, el cantar de las gacelas..." (apud MIRANDA POZA, 2007, p. 102). Além disso, é oferecido um estudo etimológico que explica a tradução proposta. Assim, a palavra adamay representaria uma forma verbal do passado relacionada com o verbo latino amare; a forma filygüelo seria um substantivo derivado da voz latina filius, com o acréscimo de um sufixo diminutivo tipicamente românico -uelo. O significado mais próximo que poder-lhe-íamos atribuir seria "garoto / garotinho" (esp. "jovenzuelo"). Por sua vez, alyenu é forma adjetiva derivada do latim alienus (moderno "alheio"). O significado seria precisamente esse: "alheio, que não pertence àquele que fala na primeira pessoa". Já ed seria uma conjunção copulativa, cuja etimologia seria a forma correspondente latina, $e t$, a partir da qual derivaram as atuais $e$ (português) e $y, e$ do espanhol. A forma que reproduz Alvar (1978), como él, coincide plenamente com a forma atual do pronome pessoal sujeito da terceira pessoa do singular masculino do espanhol (português, ele). O sintagma a mibi se aproxima da forma correspondente ao caso dativo do pronome pessoal da primeira pessoa (mihi), acrescido da preposição $a$. Kyrilu é uma forma verbal amalgamada derivada do verbo querer com o pronome pessoal de objeto direto $l u$ em ênclise. O sintagma de mi (preposição + forma derivada evoluída do dativo latino) é mostra de uma evolução ocorrida neste incipiente latim romanceado ou moçárabe em relação às estruturas do latim clássico, já superadas na fala viva, na oralidade misturada. Vetari é forma verbal relacionada com o verbo vedar: "proibir, privar, afastar". Por fim, o conjunto su al-raquīb representa, mais uma vez, uma mistura de elementos de diversas origens. Ao lado da forma romance possessiva su ("dele, dela"), aparece um substantivo plenamente árabe, inclusive com seu próprio artigo, também árabe, al-, al-raquīb, "espião, espiã". Trata-se de um traço típico dessas composições. Outras vezes, aparece repetida a forma habibi "amigo, amado, amante, namorado". A ideia geral da jarcha em tela é a evocação de uma mulher apaixonada por um homem alheio, isto é, casado, com compromisso. O alraquīb, fiscal ou protetor da situação dele, está espionando esses amores proibidos.
} 
primeiros textos poéticos da România provêm da Andaluzia. Ainda mais, na França, nos séculos XII-XIV, existia o costume de intercalar em certos poemas cultos breves canções, refrains, que são Cantigas d'Amigo à francesa: Chansons de femme, reflexo, em realidade, “de uma lírica popular muito anterior” (FRENK ALATORRE, 1978, p. 34):

$\begin{array}{ll}\text { E ai! Ke ferai? } & \text { Ay, o que farei? } \\ \text { Je muir d'amourettes } & \text { Eu morro d'amor } \\ \text { Comment garirai? } & \text { Como sararei? }\end{array}$

Nas Cantigas d'amigo galegas dos séculos XII e XIII, nos cantos tradicionais castelhanos do Renascimento e até nas Chansons de femme francesas dos séculos XII a XIV achamos elementos surpreendentemente parecidos com a primitiva lírica moçárabe. Isso não pôde acontecer por acaso. Ou eles têm uma origem comum ou sendo criação de um lugar específico foram espandidas até outras regiões. Em qualquer caso, todas as formas pertencem ao gênero da primitiva lírica europeia em língua vulgar, cantiga de amor feminina: Frauenlied (alemão), Chanson de femme (francês), Cantiga d'amigo (galego), Jarŷas (moçárabe).

Nesse sentido, Moral Molina (1993) se debruça na análise das semelhanças entre as jarŷas e a primitiva poesia galega, após estudar as contribuições de Dutton (1964) e Crespo (1967). O intuito do seu trabalho era mostrar a transmissão da literatura árabe a Ocidente através de Al-Andalus ao longo da Idade Média. O exemplo trazido pelos autores nos respectivos comentários é a célebre cantiga de Pedro Anes Solaz que contém o refrão lelia doura, edoi lelia doura, de origem árabe (séc. XIII):

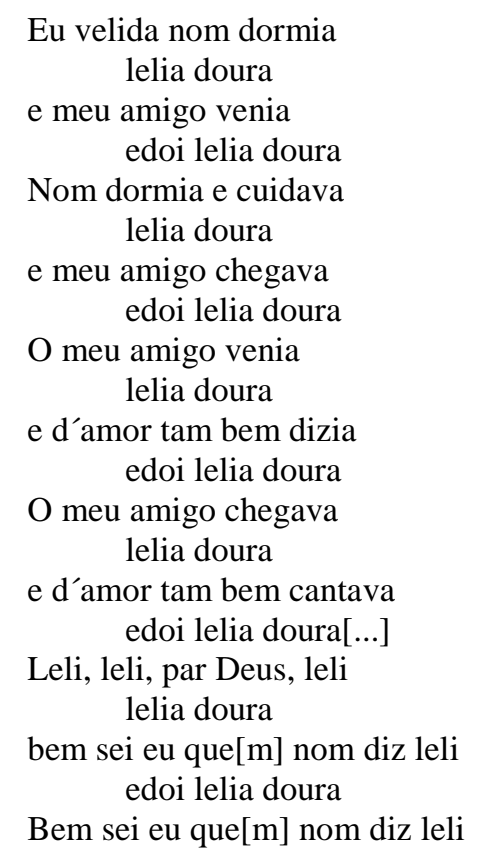




\author{
lelia doura \\ Demo x’é quem nom doz leli \\ edoi lelia doura
}

A expressão lelia doura é a transliteração aproximada do mogrevino lel yadūr "a noite roda, a noite continua". Nesse sentido, lel, lela são formas dialetais do Mogrebe dos vocábulos árabes layl / layla. Por sua vez, o ū árabe da palavra yadūr pode ser representado foneticamente pelo ditongo em português ou (como em: as-sūg > açougue). Contudo ainda o vocábulo edoi fica sem uma clara explicação (DUTTON, 1964).

Polêmicas linguísticas à parte, o que fica em evidência são as interrelações culturais e de imaginário nas manifestações literárias que representam a lírica popular: imbricações oriente-ocidente no Medioevo.

\title{
Libro de Calila e Dimna
}

Para a adequada abordagem de uma análise do Libro de Calila e Dimna é preciso fazer menção a um problema prévio: a língua (ALBORG, 1997). O latim, mesmo já em extrema corrupção, possuía ainda dignidade literária - não em vão, é conveniente lembrar que o latim era a língua da alfabetização nos redutos elitistas que acessavam esse saber. Na prosa, história, leis, livros de religião e doutrinais eram escritos em latim. As primeiras manifestações da prosa romance datam do séc. XIII e se caracterizam pela abertura a novos campos: ciência, história, pensamento. Cabe salientar o labor da Escuela de Traductores de Toledo, na época do reinado Alfonso X el Sabio, elo de união das três culturas: hebraica, árabe e latino-eclesiástica. Castela se constitui como centro de estudo intelectual do mundo árabe e, do ponto de vista linguístico, aperfeiçoa, através da escrita, a língua oral romanceada, buscando um certo tipo de padronização, em termos do próprio rei Sábio: "castellano drecho". "Se por "castellano drecho" se entende um castelhano 'apropriado' deveria ser entendido como 'direito' e sem ambiguidade'” (CÁRDENAS, 1992, p. 158, tradução nossa) ${ }^{11}$. Cano Aguilar (1985, p. 306, tradução nossa) matiza a denominação em outros termos:

[tratou-se] de uma nova tentativa integrativa externa ao próprio castelhano e interna [de reconstrução da língua na sua expansão interna]. Apesar de reconhecer a generosidade de Alfonso X na entrada de vocábulos dialetais nas obras por ele

11 "Si por "castellano drecho" se entiende un castellano 'apropiado', debería entenderse como 'correcto' y sin ambigüedad"”. 
dirigidas e revistas, o castelhano, como tal língua, terminou impondo um critério muito mais seletivo. ${ }^{12}$

Pois bem, dentre as obras que foram desenvolvidas no campo da narrativa, destaca o Libro de Calila e Dimna (1241), traduzido a partir da versão em árabe.

Trata-se de uma coleção de fábulas indianas procedentes do Panchatantra recolhidas por um médico do rei Persa Cosroes I em 570 e traduzidas para o árabe aproximadamente em 750 por Abdalá Ben Almocaffa (Ibn al-Mucafa). O título é o do primeiro dos contos, o mais extenso. Calila e Dimna são dois lobos irmãos que moravam na corte do leão. Dimna induz ao leão a matar seu privado, o boi Senceba mas, descoberta a maldade, Dimna acaba sendo condenado a morrer de fome.

As conversas entre os lobos, e as perguntas e pedidos de conselho entre um filósofo e um rei, propiciam inúmeras fábulas - a raposa e o tambor, o símio com as lentilhas, o piolho e a pulga, a lebre e os elefantes, o diabo e o ladrão, do rato e o gato: "Ahora quiero saber si los enemigos llegan a ayudarse mutuamente em momentos de tribulación" (MERINO, 2016, p. 179). A obra representa mais uma das coletâneas com manifesta intenção moral, mas de tipo pragmático: baseada na prudência e na astúcia, que ensina a se defender das vicissitudes da vida (real). Assim, após um episódio de colaboração entre o gato e o rato, primeiramente o rato comenta:

Los amigos son de dos clases. Hay amigos puros y hay otros con los que se hace amistad en horas de desolación y necesidad [...] Tú y yo somos enemigos naturales, ¿a dónde puede llevarnos el amor entre nosotros? Desde luego no sé para qué me necesitas, si no es para comerme (MERINO, 2016, p. 182-183).

Para Merino (2016, p. 11, tradução nossa), “Calila e Dimna não só não envelheceu, mas apresenta um ar surpreendente de modernidade, pois desenvolve comportamentos que podem ser projetados perfeitamente nas ambições e anseios obscuros do mundo que hoje vivenciamos". ${ }^{13} \mathrm{O}$ autor do prefácio do livro insiste num conceito fundamental da cultura árabe a propósito da leitura e do saber subsequente a ela: “Aquele que ler o livro saiba que a

\footnotetext{
12 "[se trató] de un nuevo intento integrador externo al propio castellano e interno [de reconstrucción de la lengua en su expansión interna]. A pesar de reconocer la generosidad de Alfonso X en la entrada de vocablos dialectales en las obras dirigidas y revisadas por él, el castellano, como tal lengua, terminó imponiendo un criterio mucho más selectivo.

13 “Calila e Dimna no solo no envejeció, sino que presenta un aire sorprendente de modernidad, pues desearrolla comportamientos que pueden ser proyectados perfectamente en las ambiciones y anhelos oscuros del mundo que hoy vivimos".
} 
intenção dos sábios ao comporem seus exemplos foi mostrar o saber.” (MERINO, 2016, p. 14 , tradução nossa). ${ }^{14}$

A obra, de um lado, mostra a influência nitidamente oriental, na encruzilhada medieval peninsular oriente-ocidente, mas também projeta princípios, imaginários de índole pragmática na vida que vão aparecer em obras posteriores, por exemplo, em Don Juan Manuel: saber do qual deve usar-se o leitor na vida, para evitar a perda do tempo da leitura, de onde surge o conceito amplamente estendido ao longo da Idade Média e praticamente até hoje de "leitura proveitosa" - na época medieval usava-se essa expressão para qualificar as leituras que aconteciam nos refeitórios dos mosteiros na hora das refeições. Como no Conde Lucanor, Calila e Dimna oferece no final de cada "exemplo" (capítulo, história), um provérbio que servirá de dica ao leitor: "Este es el ejemplo de lo que les puede suceder a los reyes com sus privados, y como pueden devolverles sus cargos tras castigarlos” (MERINO, 2016, p. 227).

\section{O Libro de Apolonio: História de Apolônio, Rei de Tiro.}

Uma das obras que melhor expõe a situação de interfaces oriente-ocidente, tanto pelo gênero - tão próximo da novela bizantina e os livros de viagens - quanto pelas constantes e permanentes referências ao imaginário e à cultura orientais, é o Libro de Apolonio, texto anônimo, fruto, como acima foi dito, de um particular entendimento da autoria na Idade Média e também da adaptação ao imaginário ocidental medieval, local, mais especificamente, cristão, dessas fontes pagãs.

Cerca de 100 manuscritos são os textos conservados sobre a história de Apolônio, alguns deles de tradição clássica latina. Eles constituem as fontes primárias da obra. Contínuos são os elementos pagãos, tais como as várias invocações a Netuno, as alusões a Apolo e, como acontece em certas passagens da obra, a esposa de Apolônio aguarda a chegada dele no templo de Diana. Em ecdótica, fala-se, nesses casos, da existência do hipertexto, datado no século V ou VI, a partir do qual se formaram cinco ramas ou versões gerais: A Historia Apollonii Regis Tyri; A Gesta Apollonii Regis Tyri métrica; O Phanteon, de Godofredo de Viterbo, em versos latinos, escrito entre 1186 e 1191, espécie de história universal na qual se inclui, ao lado de outros relatos, a história de Apolônio; A Gesta Romanorum, que inclui no capítulo 153 a história de Apolônio: De tribulatione temporali, que in gaudium sempiternum postremo commutabitur; Os Carmina Burana, breve texto

14 "El que lea el libro sepa que la intención de los sabios al componer sus ejemplos fue la de mostrar el saber". 
poético latino, de começos do século XIII, onde Apolônio narra sumariamente em seis estrofes as aventuras da sua vida.

Artiles (1976, p. 15, tradução nossa) afirma que o Libro de Apolonio "é uma novela bizantina versificada, metida em cânones de quaderna via". ${ }^{15}$ A estrofe denominada de quaderna via é composta por versos alexandrinos (14 ou 12 sílabas, conforme o tipo de contagem) que se repetem regularmente na estrofe de quatro versos, divididos em duas partes simétricas denominadas hemistíquios que constam de 7 (ou 6) sílabas cada um (MIRANDA POZA, 2013). No primeiro hemistíquio, para manter o ritmo do verso, aparece um acento secundário na sexta sílaba (última na contagem portuguesa) de forma paralela ao que ocorre no segundo hemistíquio (MASIP, 2002, p. 88). A cesura se manifesta na declamação por uma breve pausa e, nas edições críticas ou filológicas, é comum o costume de reproduzir um espaço em branco entre os dois hemistíquios após a cesura (MIRANDA POZA, 2007). E, como ocorre nas novelas gregas deste gênero, o poema mistura elementos da literatura sentimental e novelesca, amores impossíveis e viagens tempestuosas, perdas e reencontros.

O primeiro aspecto que merece destaque é, sem dúvida, no início da história de Apolônio, o enigma como ardil, que os pretendentes devem resolver para desposarem a filha do rei Antioco (CABAÑAS, 1998, p. 43-44):

\footnotetext{
La verdura del ramo es como la raíz, de carne de mi madre engrueso mi cerviz. Aquel que adivinase este enigma, feliz ése tendría la hija del rey emperatriz. «Tú eres la raíz, tu hija el ramal; tú pereces por ella en pecado mortal, pues hereda la hija toda deuda carnal, la cual tú y su madre teníais comunal.»
}

À tradição da Odisseia, nas fontes especificamente gregas, responde o relato das aventuras e desventuras dos protagonistas. Como na Odisseia, no Libro de Apolonio os companheiros do herói morrem e apenas ele se salva e consegue chegar à praia agarrado numa tabua:

QUADRO 2 - Comparação Libro de Apolonio / Odisseia

15 "Es una novela bizantina versificada, metida en cánones de cuaderna vía." 


\begin{tabular}{|c|c|}
\hline Libro de Apolonio & Odisseia \\
\hline $\begin{array}{l}\text { Comenzó Apolonio, de suspiros cargado, } \\
\text { dijo toda su pena, por lo que hubo pasado, } \\
\text { dónde están tierra y reino, cómo era llamado, } \\
\text { bien lo escuchó la dama teniendo gran agrado. } \\
\text { Los altos y los bajos todos de ella decían. } \\
\text { La dama y la vihuela tan bien se sucedían } \\
\text { que lo tienen a hazaña todos los que lo oían. } \\
\text { Hizo otros ejercicios que mucho más valían. }\end{array}$ & 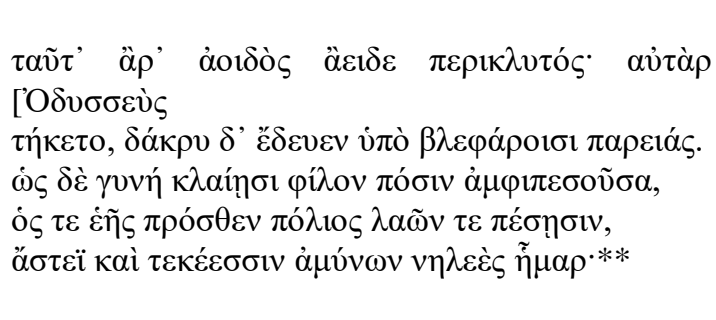 \\
\hline \multirow{2}{*}{$\begin{array}{l}\text { Alabándola todos, Apolonio callaba. } \\
\text { Pensando estuvo el rey por qué él no hablaba. } \\
\text { Le preguntó y le dijo que se maravillaba } \\
\text { que con todos los otros tan mal de acuerdo } \\
\text { estaba.* }\end{array}$} & 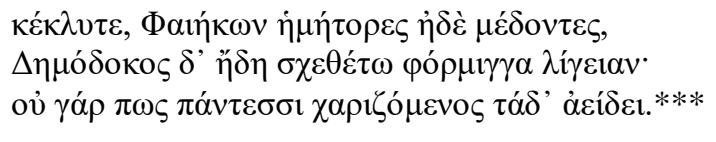 \\
\hline & $\begin{array}{l}\text { [Isso narrava o famoso cantor. Odisseu, } \\
\text { entrementes, liquefazia-se em lágrimas, tendo } \\
\text { banhadas as faces, como mulher abraçada no } \\
\text { corpo do caro marido que sucumbisse a lutar } \\
\text { junto aos muros e seus moradores, a defendê-la e } \\
\text { a seus filhos da sorte do dia impiedoso [...] Pare, } \\
\text { portanto, o cantor, porque alegres fiquemos nós } \\
\text { todos.]**** }\end{array}$ \\
\hline
\end{tabular}

Fonte: Miranda Poza (2013, p. 72)

*Citamos pela edição de Cabañas (1998, p. 66-67)

**Citamos pela edição francesa L’Odysée (1937, VIII, vv. 521-525)

***Citamos pela edição francesa L'Odysée (1937, VIII, vv. 526-538)

****Citamos pela tradução portuguesa de Carlos Alberto Nunes (2000, p. 150-151)

Já no referente às fontes latinas, nas Metamorfoses de Ovídio, a história de Filêmon e Baucis pode representar perfeitamente um antecedente textual deste episódio. Filêmon é um velho camponês, marido de Baucis, que recebeu junto com esta a visita de Júpiter, que se apresentou de incógnito na casa deles:

\author{
Iuppiter hunc specie mortali cumque parente \\ uenit Atlantiades positis caduficer alis; \\ mille domos adiere locum requiemque petentes, \\ mille domos clausere serae; tamen una recepit, \\ parua quidem stipulis et canna tecta palustri, \\ sed pia: Baucis anus parilique aetate Philemon \\ illa sunt annis iuncti iuuenalibus... (OVÍDIO NASÓN, 1994, p. 120-121)
}

["Certa vez Júpiter, sob forma humana, visitou a região, em companhia de Mercúrio (o do caduceu), sem suas asas. Apresentaram-se como viajantes fatigados, a muitas portas, procurando abrigo e repouso, mas encontraram todas fechadas. Afinal, uma moradia humilde acolheu-os, uma pequena choupana, onde uma piedosa velha, Baucis, e seu marido, Filêmon, unidos quando jovens, haviam envelhecido juntos...”] (BULFINCH, 2001, p. 62-63).

Uma vez revelada a sua verdadeira identidade - 'di' que 'sumus, meritasque luet uicina poenas / inpia' dixerunt; 'uobis inmunibus huius / esse mali dabitur', o casal foi recompensado pelos deuses, da mesma forma que aqueles que não os receberam 
adequadamente, foram punidos e morreram alagados. $\mathrm{O}$ pedido do casal aos deuses foi morrer no mesmo dia, para nunca eles sentirem respectivamente falta do outro. No Libro de Apolonio, por sua vez, na parte final do poema, o protagonista também recompensará seu hóspede ricamente (CABAÑAS, 1998, p. 132):

\begin{abstract}
Por todos los trabajos que le habían venido no olvidó el convenio que había prometido; recordó al pescador que lo había acogido, el que hubo, con él, el mantillo partido.

Dios que vive y reina tres y uno llamado, depare un tal huésped a todo hombre cuitado; bien haya tal huésped, cuerpo tan acordado, que tan buen galardón da a un hospedado.
\end{abstract}

As adivinhações são conhecidas por todos os povos desde os primórdios. Contudo a origem delas é oriental e muitas vezes expressavam os mais elevados pensamentos, apesar de terem um marcado arraigo popular: "as mais antigas conhecidas pertencem à época babilônica e aparecem escritas em tabuletas" (RASERO CHACÓN, 2004, p. 227, tradução nossa) ${ }^{16}$. Exemplos de adivinhações ou enigmas aparecem em textos bíblicos, no Alcorão, na mitologia grega e nos manuscritos sânscritos - também, como já foi dito, a trama da obra parte de uma adivinhação, um enigma, resolvido por Apolônio apesar das consequências.

As previsões dos homens resultam inúteis para preservarem-se do ditado por poderes supremos que regem o acontecer - embora não sempre seja assim, como confessa Victor Hugo no prefácio de Notre-Dame de Paris:

Há alguns anos, visitando, ou melhor, escrutando a Catedral de Nossa Senhora, o autor deste livro achou, num rincão sombrio de uma das torres, esta palavra gravada a mão no muro: ANÁГKH. Essas maiúsculas gregas [...] e, sobretudo, o sentido lúgubre que apresentavam, produziram uma viva impressão no autor [...] É a propósito dessa palavra que o livro foi escrito." (HUGO, 1904, s.p., apud MIRANDA POZA, 2014, p. 240 - tradução e grifos nossos). ${ }^{17}$

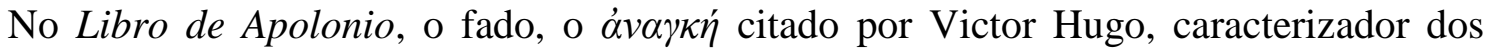
heróis épicos e de outros futuros, convive diretamente com o Espírito Santo (CABAÑAS, 1998, p. 88):

\footnotetext{
16 "Las más antiguas conocidas pertenecen a la época babilónica y aparecen escritas en tablillas."

17 "Il y a quelques années qu'en visitant, ou, pour mieux dire, en furetant Notre-Dame, l'auteur de ce livre trouva, dans un recoin obscur de l'une des tours, ce mot gravé à la main sur le mur: ANÁГKH. Ces majuscules grecques [...], et surtout le sens lugubre et fatal qu'elles renferment, frappèrent vivement l'auteur [...]. C'est sur ce mot qu'on a fait ce livre".
} 
La gente desolada y su rey descasado,

Pasaron su trayecto maldiciendo del hado.

El Espíritu Santo los guió, sosegado

así el mar, arribaron a Tarso, sitio amado

A breve análise aqui resumida do Libro de Apolonio nos conduz até a conclusão de que ele constitui um claro exemplo do que representou o medievo do ponto de vista literário e cultural, não apenas na Península Ibérica, mas também no resto da Europa. O imaginário europeu medieval foi constituindo-se sustentado, sim, na ideologia do cristianismo, mas, ao mesmo tempo, adaptando toda uma tradição clássica, pagã, que na sua versão greco-latina trazia ecos inequívocos do Oriente. De um lado, Bizâncio e o antigo império oriental romano; de outro, as influências da cultura semítica, árabe e hebraica, que chegaram à Península Ibérica a partir do século VIII e que ainda permaneciam em pleno apogeu no século XIII, época da elaboração do Libro, traziam como consequência uma mistura de motivos e tópicos que hoje devemos ser capazes de apreciar e valorar na justa medida, em especial, quando abordamos a sempre difícil tarefa de compreender um texto antigo.

\section{El Conde Lucanor de Don Juan Manuel}

"Aspecto fundamental da personalidade de Don Juan Manuel é a influência oriental que perpassa sua obra" (ALBORG, 1997, p. 288). Parece fora de dúvida que ele conhecia livros árabes que circulavam e se traduziam na Corte de Alfonso X. Sua atividade política e militar facilitava o contato com muçulmanos: participou ativamente das lutas nobiliárias tomando partido, conforme as conveniências do momento e seus próprios interesses, inclusive se juntando com o rei muçulmano de Granada.

El Conde Lucanor (1335) consta de 50 apólogos onde são oferecidos conselhos para diversos problemas: salvação das almas, das honras, das fazendas e dos estados. A estrutura é sempre a mesma: um problema da vida real do Conde é repassado para Patronio, seu privado, o qual relata um conto, cujo final contém um ensinamento ("moraleja") que resume ou transforma o particular em universal.

Don Juan Manuel deve à literatura oriental a técnica de organizar um conjunto de apólogos dentro de um marco geral e, sobretudo, do fato de ilustrar regras morais através de exemplos e contos. O princípio de exemplaridade medieval, modelo de conduta e 
comportamento para aprendizado de todos, os exempla. O esquema é simples: parte-se do caso particular narrado e se generaliza em termos de modelo de comportamento. Nesse sentido, no prólogo do Conde Lucanor, Don Juan Manuel explica (GÓMEZ REDONDO, 2008, p. 59):

\begin{abstract}
Et porque cada omne aprende mejor aquello de que se más paga, por ende el que alguna cosa quiere mostrar a otro dévegelo mostrar en la manera que entendiere que será más pagado el que la ha de aprender. Et porque a muchos omnes las cosas sotiles non les caben en los entendimientos, porque non las entienden bien [...] yo, don Iohan, fijo del infante don Manuel [...] fiz este libro compuesto de las más apuestas palabras que yo pude, et entre las palabras entremetí algunos exiemplos de que se podrían aprovechar los que los oyeren.
\end{abstract}

O sentido pragmático do saber, conforme o pensamento árabe acima exposto, segundo o qual ele deve ter um sentido prático, é evidente: “et los que lo leyeren si por su voluntad tomaren plazer de las cosas provechosas que ý fallaren, será bien; et aun los que tan bien non entendieren [...] aprovecharse an delas" (GÓMEZ REDONDO, 2008, p. 60).

O Libro apresenta fontes diversas: fábulas esópicas e orientais, parábolas, livros árabes e orientais, crônicas, relatos evangélicos, fontes orais. Alguns dos contos provêm do Calila e Dimna, como o de doña Truhana, origem do famoso Cuento de la lechera, expressão viva ainda hoje em língua espanhola. Contudo, não se trata apenas de uma coleção: o autor recria aspecto tipicamente medieval. Observe-se sua proximidade - é apenas 13 anos anterior - com o Decamerão de Boccaccio, mas sem referências ao amor carnal, tema central do segundo.

Do ponto de vista da intertextualidade, até nove contos contidos no Conde Lucanor têm origens ou influência da literatura árabe. Especialmente significativo, o Exemplo XXXV: "De lo que contesçió a un mançebo que casó con una muger muy fuerte et muy brava"18. Nele é

\footnotetext{
18 _Perro, danos agua a las manos!

El perro non lo fizo. Et él encomençóse a ensañar et díxol más bravamente que les diesse agua a las manos. Et el perro non lo fizo. Et desque vio que lo non fazía, levantóse muy sañudo de la mesa et metió mano a la espada et endereçó al perro. Quando el perro lo vio venir contra sí, començó a foýr, et él en pos él, saltando amos por la ropa et por la mesa et por el fuego, et tanto andido en pos dél fasta que lo alcançó, et cortól la cabeça et las piernas et los braços, et fízolo todo pedaços et ensangrentó toda la casa et toda la mesa et la ropa [...]

Et desque cató a una parte et a otra et non vio cosa viva, bolvió los ojos contra su muger muy bravamente et díxol con grand saña, teniendo la espada en la mano:

-Levantadvos et datme agua a las manos.

La muger, que non esperava otra cosa sinon que la despedaçaría toda, levantóse muy apriesa et diol agua a las manos. Et díxole él:

-¡A!, ¡cómo gradesco a Dios porque fiziestes lo que vos mandé, ca de otra guisa, por el pesar que estos locos me fizieron, esso oviera fecho a vos que a ellos! [...]

Et daquel día adelante, fue aquella su muger muy bien mandada et ovieron muy buena vida.

Et dende a pocos días, su suegro quiso fazer assí commo fiziera su yerno, et por aquella manera mató un gallo, et díxole su muger:
} 
defendida a posição dominante do homem com relação à mulher com a justificativa do fato de a mulher ser maldosa por natureza, assunto já previamente tratado no gênero sermão, representado na literatura castelhana pelo Corbacho, de Alfonso Martínez de Toledo, na mesma linha dos exemplos de El Conde Lucanor. "A influência árabe deve ser buscada, antes que nas fontes literárias utilizadas, direta ou indiretamente, no espírito árabe que contribui a integrar a mentalidade do autor" (SOTELO, 1995, p. 56).

\section{Considerações finais}

Em nosso trabalho revisitamos alguns dos conceitos tradicionalmente desenvolvidos pela História e a Crítica literária referentes à própria concepção de Idade Média na Península Ibérica, focando as relações políticas, sociais e culturais que se produziram entre as culturas que conviveram nesse período, em especial, das - não sempre, como às vezes a historiografia oficial espanhola espalhou durante décadas - conturbadas relações entre o Islamismo e o Cristianismo. Embasados nos trabalhos clássicos de Américo Castro a propósito da História da Espanha (2004), junto com as propostas de Maravall (1954) - também críticas em relação à visão mais tradicional do assunto, demonstramos a teoria de uma convivência não apenas cultural, mas, sobretudo, social e política entre as culturas que povoaram a Península, o qual abriu a possibilidade de uma influência palpável nas manifestações literárias da época, com a subsequente intertextualidade. Por sua vez, a cultura árabe recebera uma influência indubitável do Oriente, o que produziu que a literatura romanceada tivesse mais uma fonte de inspiração. Coube ao criador medieval peninsular a tarefa de adaptar esses referentes à realidade espaço-temporal da sua contemporaneidade, em especial no âmbito da religiosidade.

Uma vez estabelecidos os princípios teóricos acima, percorremos algumas das obras em destaque que ao longo do período medieval peninsular apresentam de forma mais acusada os fenômenos descritos. A partir dos trabalhos de Frenk Alatarrore (1978), Moral Molina (1993), Dutton (1964), ou Crespo (1967), mergulhamos no gênero e circunstâncias da produção, inclusive linguísticas, de uma das primeiras manifestações romanceadas na Península Ibérica, as Jarŷas (sec. XI), que representam a síntese da primitiva lírica europeia: Frauenlied,

-A la fe, don fulán, tarde vos acordastes, ca ya non vos valdría nada si matássedes çient cavallos: que antes lo oviérades a començar, ca ya bien nos conosçemos [...]

Et porque don Iohan lo tovo por buen enxienplo, fízolo escrivir en este libro et fizo estos viessos que dizen assí: Si al comienço non muestras qui eres,

nunca podrás después quando quisieres (GÓMEZ REDONDO, 2008, p. 162-166). 
Chanson de femme, Cantiga d'amigo (MIRANDA POZA, 2007). Mais tarde, dentro da tradição contista oriental, cabe destacar a contribuição à interculturalidade e intertextualidade do Libro de Calila e Dimna (1241), coleção de fábulas indianas procedentes do Panchatantra, recolhidas por um médico do rei da Pérsia em 570 e traduzidas para o árabe em 750 por Abdalá Ben Almocaffa (Ibn al-Mucafa). A repercussão dos contos será muito importante na literatura posterior: Libro de buen amor, El conde Lucanor, dentre outros (ALBORG, 1997; MERINO, 2016). Além do argumento dos contos, cabe salientar o espírito árabe a propósito da literatura: o exemplo tem a intenção por parte do sábio que o escreveu de mostrar seu saber para o leitor aproveitar na vida. Já o Libro de Apolonio (1260) desenvolve de forma particular um tema tomado de um romance bizantino equivalente às novelas de aventuras de hoje (ALBORG, 1997). Oferecemos, a partir dos trabalhos de Alvar (1978), Cabañas (1998) e Corbella (1992) um resumo das diversas fontes da obra, algumas delas latinas, sendo que o texto originário - em grande parte longe da versão castelhana - era grego, mais tarde passou ao latim, e a partir da versão latina conheceu, além da castelhana, outras versões - não sempre coincidentes entre si - francesa e provençal. A castelhana inclui intertextualidades com a Odisseia. Finalmente, já próximo ao período Humanista, El Conde Lucanor (1335), de Don Juan Manuel, consta de 50 apólogos, muitos deles de indubitável tradição oriental - e não só pela forma de conto (ALBORG, 1997). Sotelo (1995) determinou a influência da cultura árabe em até nove exemplos. Mas, o que deve ser destacado como conclusão é que devemos entender como fato significado do Medievo a prolongada e profícua interação das duas culturas em foco (islâmica e cristã) que eram diferentes e que conviveram num mesmo território. Por fim, cabe salientar que, muito além das fontes literárias concretas, o espírito árabe (e oriental) perpassaram a mentalidade do autor peninsular, fruto inequívoco da realidade política, social e cultural que vivenciava.

\section{Referências}

ALBORG, J. L. Historia de la Literatura Española. Tomo I: Edad Media y Renacimiento. 2 ed. ampl. Madrid: Gredos, 1997.

ALONSO, D. Cancioncillas 'de amigo' mozárabes. (Primavera temprana de la lírica europea). Revista de Filología Española, Madrid, n. 33, p. 297-349, 1949.

ALVAR, M. Poesía Española Medieval. Barcelona: Planeta, 1978. 
ÁLVAREZ, A. Enciclopedia. Intuitiva, sintética, práctica. Tercer Grado. Ed. facsímil. Madrid, México, Buenos Aires: Edaf, 2000.

ARTILES, J. El “Libro de Apolonio”, poema español del siglo XIII. Madrid: Gredos, 1976.

BAUMAN, Z. Identidade: entrevista a Benedetto Vecchi. Tradução de Carlos Alberto Medeiros. Rio de Janeiro: Jorge Zahar, 2005.

BRUYNE, E. La estética de la Edad Media. Madrid: Visor, 1988.

BULFINCH, T. O livro de Ouro da Mitologia. (A Idade da Fábula). Histórias de Deuses e Heróis. 13 ed. Tradução de David Jardim Júnior. Rio de Janeiro: Ediouro, 2001.

CALILA y Dimna. Ed. de José María Merino. Madrid: Páginas de Espuma, 2016.

CANO AGUILAR, R. Castellano ¿drecho? Verba, v. XII, p. 287-306, 1985.

CÁRDENAS, A. Alfonso X nunca escribió “castellano drecho". Congreso de la Asociación Internacional de Hispanistas, 10, 1989, Barcelona. Anais... Barcelona: Promociones y Publicaciones Universitarias S.A., 1992, p. 151-159. Disponível em:

<https://cvc.cervantes.es/literatura/aih/aih_x.htm>. Acesso em: 12 abr. 2020.

CASTRO, A. La realidad histórica de España. México: Editorial Porrúa, 1954.

España en su historia. Ensayos sobre historia y literatura. Obra reunida, vol. III. Madrid: Trotta, 2004.

CRESPO, F. Lelia Doura ou o estranho refrão de uma cantiga trovadoresca. Colóquio, Lisboa, n. 42, p. 54-55, fev. 1967. Disponível em:

<http://coloquio.gulbenkian.pt/al/sirius.exe/artigo?1227>. Acesso em: 12 abr. 2020.

DON JUAN MANUEL. Libro del Conde Lucanor. Con cuadros cronológicos, introducción, texto selecionado, bibliografía, notas y llamadas de atención, documentos y orientaciones para el estudio a cargo de Fernando Gómez Redondo. Madrid: Editorial Castalia, 2008.

El Conde Lucanor. Ed. de Alfonso I. Sotelo. Madrid: Cátedra, 1995.

DUTTON, B. Lelia Doura, Edoy Lelia Doura. An Arabic Refrain in a Thirteenth-Century Galician Poem? Bulletin of Hispanic Studies, v. 41, n. 2, p. 1-9, 1964.

FRENK ALATORRE, M. Estudios sobre lírica antigua. Madrid: Castalia, 1978.

GALMÉS DE FUENTES, A. Mozárabe. In: ALVAR, M. (Dir.) Manual de dialectología hispánica. El español de España. 4 ed. Barcelona: Ariel, 2007, p. 87-110.

GUILLÉN, C. Entre lo uno y lo diverso. Barcelona: Crítica, 1985.

HALL, S. A identidade cultural na pós-modernidade. 11 ed. Rio de Janeiro: DP\&A, 2006. 
HODOI ELEKTRONIKAI. Du texte à l'hypertexte. Homère, Odyssée. Traduction française. Paris: E. Flammarion, 1937.

HOMERO. Odisseia. Tradução de Carlos Alberto Nunes. Rio de Janeiro: Ediouro, 2000.

HUGO, V. Notre-Dame de Paris. Paris: Librairie Ollendorff, 1904. Disponível em: https://fr.wikisource.org/wiki/Notre-Dame_de_Paris/Pr\%C3\%A9face Último acesso: 14/04/2020.

Libro de Apolonio. Texto íntegro en versión del Dr. D. Pablo Cabañas. Madrid: Castalia, 1998.

Libro de Apolonio. Ed. de Dolores Corbella. Madrid: Cátedra, 1992.

MARAVALL, J. A. El concepto de España en la Edad Media. Madrid: Instituto de Estudios Políticos, 1954.

MASIP, V. Manual de poesía española y portuguesa. Recife: AECI / Bagaço, 2002.

MENÉNDEZ PIDAL, R. Estudios sobre lírica medieval. Ed. de Ernesto Barroso e Marta Latorre. Madrid-Valladolid: Centro para la Edición de los Clásicos Españoles, 2014.

MICHAEL, I. Epic to Romance to Novel: Problems of the Genre Identification. Bulletin of the John Ryland's University Library of Manchester, n. 68, p. 498-527, 1986.

MIRANDA POZA, J. A. Breves apuntes sobre historia, lengua y cultura sefardíes. In: CORDIVIOLA, A.; ANDRADE, B. C. (orgs.) Hispanismos: outras margens. São Paulo: ABH - Associação Brasileira de Hispanistas, 2019, p. 66-95.

El problema de España en la encrucijada histórica del 98. Madrid: Espacio, Tiempo y Pueblo en "La lucha por la vida", de Pío Baroja. In: Colóquio Internacional Literatura e Gênero, 2, 2014, Teresina. Anais... Teresina: UESPI, 2015, p. 1-13.

La recepción de La vida es sueño en el marco de la enseñanza de la literatura española en Brasil. Congreso Extraordinario de la Asociación Internacional de Teatro Español y Novohispano de los Siglos de Oro, 2012, Vitória. Anais... Vitória: Programa de Pós Graduação em Letras da UFES / AITENSO, 2014, p. 235-254.

O Libro de Apolonio na encruzilhada da poesia castelhana do século XIII.

Originalidade e adaptação ao imaginário europeu medieval de fontes orientais e clássicas. In: SENA, A. (org.) Literatura fantástica e orientalismo. Recife: Editora Universitária da UFPE, 2013, p. 59-90.

La Edad Media en Europa como marco para el estudio de la época literária medieval. In:___ (org.) Estudios Hispánicos. Recife: Editora Universitária da UFPE / Pró-Reitoria de Extensão, 2011, p. 159-169.

Poesía española medieval (I): Época de Orígenes, Épica y "Mester de Juglaría". In: ; RODRIGUES, J. P. M. (Orgs.) Estudios de Lengua y Literatura Española. 
Recife: Departamento de Letras da UFPE / Associação de Professores de Espanhol do Estado de Pernambuco - APEEPE, 2007, p. 101-122.

MORAL MOLINA, C. Huellas de la Literatura árabe clásica en las literaturas europeas. Vías de transmisón. In: MUÑOZ, F. (org.) Confluencia de culturas en el Mediterráneo.

Granada: Eirene - Seminario de Estudios sobre la Paz y los Conflictos / Universidad de Granada, 1993, p. 193-215.

ORTEGA Y GASSET, José. España Invertebrada. Madrid: Revista de Occidente, 1922. Disponível em: <http://juango.es/files/Ortega-Y-Gasset---Espana-Invertebrada.pdf>. Acesso em: 11 abr. 2020.

OVÍDIO NASÓN, P. Metamorfosis. Texto revisado e traduzido por Antonio Ruiz de Elvira. 3 vols. Madrid: Consejo Superior de Investigaciones Científicas, 1994.

PEREIRA, B. N.; MIRANDA POZA, J. A. "Nada", de Carmen Laforet y "El Jarama”, de Sánchez Ferlosio: la desilusión y el tedio en la juventud de la España de la pós-guerra. Colóquio Internacional Literatura e Gênero, 2, 2014. Anais... Teresina: UESPI, 2015, p. 1431.

PONTES, R. A Idade Média nos estudos residuais. Graphos, João Pessoa, v. 17, n. 2, p. 27 $32,2015$.

RASERO CHACÓN, J. Adivinanzas y trabalenguas: Posibilidades didácticas. In: BARCIA MENDO, E. (org.) La tradición oral en Extremadura. Mérida: Junta de Extremadura Consejería de Educación, Ciencia y Tecnología, 2004, p. 221-247.

TODOROV, T. Introducción a la literatura fantástica. Buenos Aires: Tiempo Contemporáneo, 1972.

TUSÓN, V.; LÁZARO, F. Literatura española. Madrid: Anaya, 1980.

VICENS-VIVES, J. España contemporánea. Barcelona: El Acantilado, 2012.

ZAMORA VICENTE, A. Dialectología española. 2 ed. aum. Madrid: Gredos, 1996.

Recebido em: 16/07/2020

Aceito para publicação em: 23/11/2020 